\title{
PERAN ORANG TUA DALAM PEMBELAJARAN MODEL DISTANCE LEARNING DI SEKOLAH DASAR KOTA JAYAPURA
}

\author{
Didik Efendi \\ Dosen, IAIN Fattahul Muluk Papua, Indnesia \\ Email: didik.kotjap@gmail.com
}

\begin{abstract}
This research aimed to figure out the role of parents in assisting elementary students' learning through a distance learning model in Jayapura and its problems faced by the parents. This qualitative research was conducted in Jayapura City, Papua Province. Data collection techniques of this research used interview and questionnaire which was distributed by using google form to the subjects. The findings showed that there were four roles of parents in assisting elementary students' learning through a distance learning model, namely (1) Educator, meaning that the parents performed as a mentor and teacher of the children at home; (2) Motivator, meaning that the parents motivated their children continuously during distance learning model; (3) Facilitator, meaning that the parents provided facilities and conveniences for their children and provide various learning resources for their children; (4) Inspirator, meaning that the parents became a model for their children as they act as teacher. The problems faced by parents in a distance learning were (1) difficult to manage the time; (2) unstable network; (3) they fear a new technology (technophobe); (4) require patience; and (5) the way to provide assistance when the parents were at work.

Keywords: Role, parents, distance learning
\end{abstract}

\section{PENDAHULUAN}

Belajar merupakan suatu upaya seseorang secara sengaja untuk memperoleh sesuatu yang belum dipahami baik pengetahuan maupun tindakan sehinga memungkinkan seseorang berupag dalam berpikir dan bertindak. Belajar tidak hanya suatu aktifitas menghafal maupun berhitung namun belajar harus disertai adanya perubahan (hasil belajar). Hasil belajar peserta didik dapat dipengaruhi beberapa faktor, diantaranya adalah faktor guru. Guru mempunyai andil yang cukup besar dalam belajar peserta didik di sekolah. Peran guru bagi anak usia sekolah dasar sangat penting. Peran ini tidak bisa digantikan oleh kecanggihan teknologi, seperti internet, komputer, radio dan media pembelajaran lainnya. Karena anak usia sekolah dasar adalah individu yang memerlukan bimbingan dalam belajar.

Bulan Desember 2019 dunia dikejutkan dengan virus yang tidak tampak wujudnya namun sangat mematikan. Virus tersebut dijuluki dengan covid-19. Covid-19 adalah penyakit menular yang disebabkan oleh jenis coronavirus yang baru ditemukan. Beberapa jenis coronavirus diketahui menyebabkan infeksi saluran nafas pada manusia mulai dari batuk pilek hingga yang lebih serius seperti Middle East Respiratory Syndrome (MERS) dan Severe Acute Respiratory Syndrome (SARS). Covid-19 dapat menyebar dari orang ke orang melalui percikan-percikan dari hidung atau mulut yang keluar saat orang yang terjangkit covid-19 batuk atau mengeluarkan nafas. Percikan-percikan ini kemudian jatuh ke benda-benda dan permukaanpermukaan di sekitar. Orang yang menyentuh benda atau permukaan tersebut lalu menyentuh mata, hidung 
atau mulutnya, dapat terjangkit covid-19. Penularan covid-19 juga dapat terjadi jika orang menghirup percikan yang keluar dari batuk atau napas orang yang terjangkit covid-19.

Dengan adanya covid-19, pemerintah membatasi semua kegiatan, baik itu sekolah, perkantoran maupun lainya yang mengundang masa banyak/ kerumunan masa. Hal ini dilakukan guna memutus rantai penyebaran covid-19. Kota Jayapura yang terletak di provinsi Papua menjadi korban dari virus covid-19, tercatat dibulan Maret 20205 warga kota Jayapura positif terpapar virus covid-19 dan masih banyak yang ODP (orang dalam Pantuan) dan PDP (Pasien dalam Pantuan) yang masih dalam pengawasan dan penanganan pemerintah kota Jayapua. Untuk menyikapi situasi yang semakin tidak kondusif terkait penyebaran virus covid-19, maka pemerintah kota Jayapura dengan merujuk (1) Surat Edaran nomor 15 Tahun 2020 Tentang Pedoman Penyelenggaraan belajar dari rumah dalam masa darurat penyebaran Corona Virus Disease (Covid-19), (2) Surat edaran Mendikbud Nomor 4 tahun 2020 tentang pelaksanaan Kebijakan pndidikan dalam masa Darurat penyebaran Covid-19 memberlakukan pelaksanaan Belajar Dari Rumah (BDR) di semua jenjang Pendidikan.

Adapun tujuan BDR selama darurat covid-19 Bertujuan adalah (1) memastikan pemenuhan hak peserta didik untuk mendapatkan layanan Pendidikan selama covid-19, (2) mencegah penyebaran dan penularan covid-19 disatuan Pendidikan, (3) memastikan pemenuhan dukungan psikososial bagi pendidik, peserta didik dan orang tua. Dengan pelaksanaan BDR maka peran guru dalam membimbing, mendidik dan mengajar sepenuhnya menjadi tanggung jawab orang tua.

Masyoritas masyarakat kota Jayapura adalah berkarir, berdagang dan PNS terkadang mereka jarang bisa menampingi anak dalam belajar. Pada umumnya orang tua peserta didik pergi pagi dan pulang malam. Anak disekolahkan full day atau di rumah di temani oleh pembantu. Pada saat virus covid-19 melanda kota Jayapura, orang tua peserta didik kualahan dalam mendampingi anaknya dalam belajar. Keluhan orang tua terhadap anak belajar di rumah membanjiri di wa grup guru maupun sosial media. Mayoritas orang tua menginginkan covid-19 segera berlalu dan anak bisa bersekolah lagi. Selain keluhan dari orang tua, peserta didik juga mengeluh dengan metode yang digunakan orang tua dalam mendampinginya dalam belajar.

Ketidaksesuaian metode mengajar orang tua dalam pendampingan belajar anak akan menyebabkan anak kurang termotivasi dalam belajar dan akan berdampak pada hasil belajar anak. Keberhasilan belajar peserta didik di rumah sepenuhnya pengaruh dari pendampingan orang tua. Anak usia sekolah dasar dalam tahap perkembangannya dan belajarnya masih butuh pendampingan orang tua. Orang tua menentukan kesuksesan belajar anak di rumah.

Pembelajaran jarak jauh (Distance learning ) digadang-gadang sebagai solusi dalam pembelajaran di era covid-19. Pembelajaran jarak jauh dapat dibagi menjadi 2 pendekatan, yakni pembelajaran daring (dalam jaringan) dan pembelajaran luring (luar jaringan). Pemblajaran daring dapat mengunakan beberapa aplikasai sperti cloudx, zoom, Skype dan lainnya diharapkan memudahkan pembelajaran daring. Selain itu kementrian pendidikan juga menyediakan beberapa situs untuk di akses sebagai sumber belajar daring seperti Rumah 
Belajar (http://belajar.kemendikbud.go.id), Pembelajaran digital (https://rumahbelajar.id) dan TV Edukasi Kemendikbud (http://tve.kemendikbud.go.id/live/) lain sebagainya Sedangkan pembelajaran luring dapat menggunakan sumber dan media pembelajaran seperti televisi, radio, modul, bahan cetak, alat peraga dan media belajar dari benda dan lingkungan sekitar.

Namun dalam perjalannya harapan tersebut tidak seindah yang dibayangkan. Banyak kendala yang di hadapi guru, orang tua maupun peserta didik dalam pembelajaran jarak jauh Dilihat dari kendala guru adalah guru kesulitan mengelola pembelajaran jarak jauh, peserta didik yang tidak didampingi orang tua sulit untuk menerima materi yang di sampaikan dalam pembelajaran daring, guru kesulitan dalam mengatur jadwal secara bersamaan karena beberapa peserta didik tidak memiliki HP dan orang tua bekerja. Kendala yang di hadapi orang tua contohnya orang tua tidak bisa mendampingi anaknya belajar di rumah secara maksimal karena kerja di luar rumah. Selain itu, orang tua dalam memahami pelajaran dan memotivasi anak saat mendampingi belajar di rumah. Sedangkan kendala yang dihadapi peserta didik adalah kesulitan kosentrasi belajar dari rumah dan mengeluhkan beratnya penugasan dari guru dan peningkatan rasa stres dan jenuh akibat isolasi berkelanjutan berpotensi menimbulkan rasa cemas dan depresi bagi anak.

Dari berbagai kendala-kendala tersebut maka perlu peran orang tua yang maksimal untuk mendampingi anak dalam pembelajaran jarak jauh (Distance learning). Dalam pendampingan Distance learning orang tua harus memperhatikan beberapa aspek, yaitu aspek knowledge (pengetahuan), interest (minat), value (nilai), attitude (sikap) dan understading (pemahaman). Selain itu orang tua harus mengetahui karakteistik belajar anak dan strategi atau upaya-upaya orang tua agar anak bisa belajar dengan efektif dan efesien. Anak usia sekolah dasar belum mampu belajar mandiri tanpa ada penjelasan dan pendampingan orang orang tua. Anak usia sekolah dasar dalam belajarnya masih membutuhkan bantuan oraang lain untuk mengkonkritkan materi yang akan dicernanya. Hal ini sesuai dengan tingkat perkembangan kognitif anak tersebut yakni masih dalam tahap perkembangan operasional konkrit, yaitu dalam belajar anak tersebut orang tua harus menghadirkan pembelajaran secara konkrit.

Tujuan penelitian ini adalah untuk mendiskripsikan bagaimana peran orang tua dalam dalam pendampingan pembelajaran model Distance learning pada anak usia sekolah dasar di kota Jayapura serta problem yang dihadapi orang tua dalam pembelajaran model Distance learning.

\section{METODE PENELITIAN}

Penelitian ini menggunakan pendekatan kualitatif. Penelitian kualitatif adalah suatu penelitian yang ditujukan untuk mendiskripsikan dan menganalisis fenomena, peristiwa, aktifitas sosial, sikap, kepercayaan, persepsi, pikiran orang secara individu maupun kelompok ${ }^{1}$. Penelitian ini bertujuan untuk mendeskripsikan tentang peran orang tua dalam pembelajaran jarak jauh pada anak usia sekolah dasar di kota Jayapura.

\footnotetext{
${ }^{1}$ Nana Syaodih Sukmadinata, Metode Penelitian Pendidikan (Bandung: PT Remaja Rosdakarya, 2015), h. 60
} 
Lokasi penelitian di kota Jayapura provinsi Papua dengan sumber data yang digunakan adalah data primer dan sekunder. Data primer didapatkan dari orang yang diwawancari melalui wawancara, sedangkan data sekunder diperoleh dari selain data wawancara. Adapun teknik pengumpulan data dilakukan dengan wawancara dan penyebaran angket secara online menggunakan goggle form.

Dalam penelitian ini menggunakan teknik analisis data dengan model Miles dan Huberman. Adapun tahap-tahapnya sebagai berikut (1) Pengumpulan data. Pengumpulan data adalah proses pengumpulan data mentah baik data primer maupun skunder dengan cara wawancara dan penyebaran angket, (2) reduksi data, yakni salah satu tahapan untuk menganalisis dengan cara memlilah dan memilih atau menggolongkan dan mengorganisasikan data-data lapangan, (3) Display data, yakni merupakan proses penyajian data secara sederhana dalam bentuk kata-kata atau kalimat yang dinarasikan agar mepermudah peneliti dalam menarik kesimpulan. (4) penarikan kesimpulan dan verifikasi data, yakni pada tahapan ini peneliti menarik sebuah kesimpulan dari hasil penelitian serta meverivikasi data dengan cara menguji kebenaran dari kesimpulan yang diperoleh.

\section{HASIL DAN PEMBAHASAN}

\section{Konsep Pembelajaran Jarak jauh (Distance learning)}

Virus covid-19 memberikan dampak pada semua sektor, baik perekonomian, pariwisata dan pendidikan. Virus covid-19 memberikan tatanan baru dalam pendidikan. Sebelum adanya virus covid-19 pembelajaran dilaksanakan di sekolah dengan tatap muka secara langsung, namun dengan adanya virus covid-19 membelajaran harus dilaksanaknan dengan tatap maya sesuai anjuran menteri Pendidikan dan kebudayaan yang tertuang dalam surat edaran nomor 4 Tahun 2020 tentang pelaksanaan kebijakan dalam masa darurat penyebaran covid-19 yang isinya proses belajar dilakukan di rumah melalui pembelajaran jarak jauh. Pembelajaran di rumah dapat berjalan dengan maksimal apabila ada dari dukungan orang tua dan fasilitas yang memadahi.

Belajar di rumah atau sering disebut BDR terbagi menjadi dua macam, yakni pembelajaran dalam jaringan (daring) dan pembelajaran di luar jaringan (luring). Pembelajaran dengan model Distance learning dapat dipahami proses belajar mengajar yang guru dan peserta didiknya berada di lokasi terpisah baik dalam jarinagan atau di luar jaringan. Dengan Distance learning guru dan peserta didik mempunyai keluwesan dalam belajar dalan hal waktu dan tempat belajar dengan menggunakan beberapa aplikasi seperti zoom, cloudex, google meet, youtube, wa grup, TV, radio, buku, bahan ajar dan benda-benda di sekitar. Ciri khas dari Distance learning adalah pembelajaran yang dikelola dengan mengatur belajar mandiri serta tidak ada kontak secara langsung antara guru dan peserta didik.

Prinsip dalam pembelajaran model Distance learning adalah (1) Akses; pembelajarannya dapat diakses oleh peserta didik. (2) Pemerataan; peserta didik memperoleh hak untuk memperoleh kesempatan dalam proses pembelajaran, baik dari segi waktu dan bahan ajar, (3) Kualitas; walaupun Distance learning 
merupakan pembelajaran tanpa tatap muka tetapi tidak mengurangi kualitas dalam proses pembelajaran, baik secara materi dan proses pembelajarannya. Dalam penyelenggaraan Distance learning di sekolah dasar harus sesuai dengan Standar Nasional Pendidikan (SNP) dengan mengutamakan hal-hal sebagai berikut; (1) Penggunaan berbagai media komunikasi, antara lain media elektronik, dan bentuk-bentuk media komunikasi lain yang dimungkinkan oleh perkembangan teknologi untuk menggantikan pembelajaran tatap muka dengan interaksi pembelajaran berbasis TIK; (2) Penggunaan sistem penyampaian pembelajaran yang peserta didik dengan pendidiknya terpisah; (3) Penggunaan metode pembelajaran interaktif berdasarkan konsep belajar mandiri, terstruktur, dan terbimbing yang menggunakan berbagai sumber belajar dan dengan dukungan bantuan belajar serta fasilitas pembelajaran; (4) Menjadikan media pembelajaran sebagai sumber belajar yang lebih dominan daripada pendidik.

Ragam belajar dengan model Distance learning diantaranya (1) Belajar mandiri: pembelajaran yang dilakukan oleh peserta didik dalam waktu yang telah ditentukan. Guru memberikan tugas yang dapat membantu peserta didik belajar secara mandiri. (2) Belajar terbimbing/terstruktur; pembelajaran yang dilakukan oleh guru untuk membantu peserta didik dalam pross pembelajaran secara online (daring). Adapun media dalam pembelajan model Distance learning seperti classroom, video converence, telepon atau live chat, zoom maupun melalui whatsapp group.

Adapun karakteristik pembelajaran model Distance learning sebagai berikut:

1. Proses pembelajaran harus bersifat interaktif, holistik, integratif, saintifik, kontekstual, tematik, efektif, dan berpusat pada peserta didik.

2. Pembelajaran dilakukan berbasis daring (dalam jaringan)

3. Pembelajaran harus tercipta interaksi antara guru dan peserta didik

4. Pembelajaran harus menarik dan tidak membosankan

5. Pembelajaran mudah di akses dan dipahami peserta didik

\section{Peran orang tua dalam pembelajaran model Distance learning}

Belajar menurut Gadne sebagaimana dikutip oleh Susanto adalah suatu proses dimana organisme berunah perilakuknya sebagai akibat pengalaman. Gadne juga menjelaskan belajar dapat dimaknai suati proses untuk memeperoleh motivasi dalam pengetahuan, keterampilan, kebiasaan dan tingkah laku. Selanjutnya Gadne menjelaskan dalam teorinya the domains of learning, menyimpulkan bahwa segala sesuatu yang dipelajari manusia dapat dibagi menjadi lima hal, yaitu (1) keterampilan motorik (motor skill); (2) informasi verbal; (3) kemampuan intelektual; (4) strategi kognitif dan (5) sikap (attitude)². Belajar tidak hanya menghafal dan bukan pula mengingat ataupun mendapatkan tranferan materi dari pendidik tetapi belajar adalah suatu proses yang perubahan pada diri seseorang baik perubahan secara kognitif, afektif dan psikomotorik.

\footnotetext{
${ }^{2}$ Ahmad Susanto, Teori Belajar dan Pembelajaran di Sekolah Dasar (Jakarta: Kencana, 2013). h. 1-2
} 
Belajar di era covid-19 mempunyai keunikkan tersendiri, dimana dalam masa normal anak usia SD dapat belajar dan bermain bersama guru dan teman sebayanya, namun di era covid-19 peserta didik harus belajar mandiri dengan didampingi orang tua. Menurut penelitian Agus dkk, dampak dari belajar di rumah bagi peserta didik adalah (1) fasilitas kurang memadahi untuk melakuan proses pembelajaran jarak jauh, seperti leptop, komputer, hp dan jaringan internet; (2) budaya belajar jarak jauh merupakan hal yang baru bagi peserta didik dan perlu waktu untuk beradaptasi; (3) dengan sekolah diliburkan terlalu lama membuat peserta didik bosan di rumah, mereka tidak bisa bermnain dengan teman sebayanya atau gurunya secara langsung; (4) dengan kurangnya interaksi antar teman sebagay atau guru menjadikan jiwa sosial peserta didik berkurang ${ }^{3}$.

Di era covid-19 orang tua mempunyai peranan yang cukup penting dalam belajar anak di rumah. Peranan berasal dari kata dasar peran yang artinya merupakan pola tingkah laku tertentu yang merupakan ciri-ciri khas semua petugas dari pekerjaan atau jabatan tertentu. ${ }^{4}$ Peran orang tua dalam proses pembelajaran model distance learning adalah suatu pola tingkah laku atau perbuatan merupakan ciri khas yang dimiliki orang tua dalam mendampingi pembelajaran model distance learning. Orang tua terdiri dari Ayah, Ibu atau orang yang dituakan yang memberikan nafkah, pendidikan, pelindung, memberikan rasa aman, mencurahkan rasa kasing sayang dan lain sebagainya.

Pada hakekatnya orang tua adalah pendidikan yang sejati untuk anak-anaknya. Namun dengan adanya kesibukan pekerjaan dan cari nafkah sebagian kewajiban mendidik anak di alihkan kepada guru di sekolah. Adanya covid-19 mengharuskan orang tua kembali mengambil peran pendidik yang utama. Hal ini menyebabkan banyak orang tua kualahan dalam mengajar anak di rumah. Orang tua belum terbiasa dengan mengajar anak di rumah sehingga banyak orang tua tidak sanggup salam mengajar anak di rumah..

Pembelajaran model distance learning dijadikan salah satu alternaif model pembelajaran di era covid-19. Demi keseleamatan peserta didik maka pemerintah melalui Menteri Pendidikan dan kebudayaan menginstruksikan pembelajaran di zona merah dilakukan dengan pembelajaran tatap maya atau pembelajaran daring (dalam jaringan). Orang tua mempunyai peranan yang penting dalam pembelajaran jarak jauh. Walaupun pembelajaran dilakukan secara jarak jauh, namun konsep pembelajaran kontektual dapat di interasikan dalam proses pembelajaran model distance learning.

Menurut Fauzan Pembelajaran konstektual harus memenuhi tujuh unsur, yakni (1) Construktivisme; belajar adalah proses aktif mengkonstruksi pengetahuan dari pengalaman yang di alami peserta didik secara langsung. Peserta didik tidak anya menerima tranferan pengetahuan dari pendidik tetapi harus membangun sendiri pengetahuanya. (2) Inqury; inquri merupakan untuk melatih peserta didik dapat berpikir secara nyata dan kritis. Adapun tahap-tahapnya adalah diawali dengan observasi, menentukan hipotesis, mengumpulkan

\footnotetext{
${ }^{3}$ Agus Purwanto, dkk, "Studi Eksploratif Dampak Pandemi Covid-19 Terhadap Proses Pembelajaran Online di Sekolah Dasar", Journal of Education, Psychology and Counseling Vol, 2 No. 1 (2017). h. 165-170.

${ }^{4}$ Oemar Hamalik, Psikologi Belajar dan Mengajar (Bandung: Sinar baru Algensindo, 2007), h. 33
} 
data dan menarik kesimpulan. (3) Questioning; Questioning digunakan pendidik untuk mendorong, membimbing dan menilai serta menggali informasi tentang pemahaman, perhatian dan pengetahuan peserta didik. (4) Learning Community; belajar dilakukan dalam kelompok-kelompok kecil serta berkolaboratif antar sesama peserta didik. (5) Modeling; guru adalah kepanjangan di tiru dan di gugu, artinya guru harus menjadi model bagi peserta didik. Modeling adalah salah satu pembelajaran memberikan contoh atau teladan kepada peserta didik. Modeling merupakan asas yang cukup penting dalam pembelajaran CTL sebab memlaui modeling peserta didik terhindar dari pembelajaran yang teoritis-abstrak yang dapat memungkinkan terjadinya verbalisme. (6) Reflection; cara berpikir apa yang baru dipelajari, sehingga ada respon kejadian, aktifitas/ pengetahuan yang baru. (7) Autentic Assesment; dalam proses pembelajaran harus ada penilaian secara autentik yang melibatkan tiga aspek, yakni sikap, pengtahuan dan keterampilan. ${ }^{5}$

Dalam konsisi normal, menurut Dimyati dan Mudjiono permasalahan belajar yang dialami peserta didik disebabkan dua factor, yakni faktor internal yang mencangkup sikap dalam belajar, motivasi dalam belajar, konsentrasi dalam belajar, mengelolah bahan belajar, menyimpan pemerolehan hasil belajar, menggali hasil belajar, kemampuan berprestasi atau unjuk hasil belajar, rasa percaya diri, intelengensi, kebiasaan belajar kemudian yang akhirnya cita-cita peserta didik. Sedangkan faktor eksternalnya adalah guru, sarana dan prasanan, kebijakan penilaian, lingkungan sosial di sekolah dan kurikulum sekolah. ${ }^{6}$

Anak usia sekolah dasar mempunyai keunikan tersendiri dalam belajarnya. Mereka dalam proses belajar tidak mau ada tekanan dari pihak manapun. Karakteristik anak yang suka bermain, berkelompok dan bergerak menjadi ciri khas belajar mereka. Namun adanya pandemi covid 19 membuat hak mereka bermain, berkelompok dan bergerak bersama teman sekolahnya ditiadakan. Mereka harus belajar di rumah secara pembelajaran daring atau pembelajaran luring. Pembelajaran dengan model Distance learning dijadikan alternatif dalam pembelajaran di era pandemi COVID-19. Tetapi Distance learning tidak mudah seperti yang dibayangkan, apalagi diterapkan di sekolah dasar. Salah satu permasalahnanya adalah ketika pembelajaran menggunakan zoom meeting, tidak semua anak bisa akses karena ada yang orang tuanya masih kerja, ada juga orang tua yang gagap teknologi serta kurang memadai fasilatas yang ada dirumah.

Selain itu, peserta didik dengan umur 6 atau 7 tahun sampai 12 tahun mempunyai karakterisitik yang unik dan berbeda dengan yang lainnya. Untuk memahami karakteristik anak usia sekolah dasar dalam proses pembelajaran perlu memperhatikan beberapa aspek perkembangan. Pertama, Perkembangan Kognitif. Kognitif merupakan pola berpikir individu dalam menghubungkan, menilai dan mempertimbangan sesuatu kejadian aatu peristiwa. Menurut Piaget perkembangan kognitif anak usia 7-12 tahun ditandai kemampuan dalam proses berpikir untuk mengoperasikan kaidah-kaidah logika meskipun masih terikat dengan bendabenda konkret. Adapun faktor-faktor yang mempengaruhi perkembangan kognitif anak diantaranya keturunan, lingkungan, kematangan, pembentukan, minat dan bakat, dan kebebassan. Kedua. Perkembangan

\footnotetext{
${ }^{5}$ Fauzan, Kurikulum \& Pembelajaran (Tangerang Selatan: Gaung Persada (GP) Press, 2017). h. 179-181

${ }^{6}$ Dimyati, Mudjiono, Belajar dan Pembelajaran (Jakarta: PT Rineka Cipta, 2006). h. 235-254
} 
bahasa. Bahasa adalah sarana berkomunitasi dengan orang lain. Pada masa ini merupakan masa berkembang pesatnya kemampuan mengenal dan menguasai perbendaharaan kata. Menurut Syamsu Yusuf sebagaimana dikutip Ahmadi bukunya menjelaskan bahwa perkembangan bahasa mencakup semua cara untuk berkomunikasi, dimana pikiran da perasaan dinyatakan dalam bentuk tulisan, lisan isyarat atau gerak dengan menggunakan kata-kata, kalimat bunyi, lambang, gambar dan lukisan. Dari penjelasan ini dapat dipahami bahwa dalam pembelajaran model Distance learning harus memperhatikan tingkat perkembangan anak. ${ }^{7}$

Berdasarkan tingkat perkembangan peserta didik di sekolah dasar maka orang tua harus menandampingi peserta didik dalam pembelajaran jarak jauh. Hal-hal yang dilakukan dalam proses pembelajarn dengan model Distance learning sebagai berikut: (1) orang tua menampingi dan memantau proses belajar peserta didik; (2) orang tua medorong peserta didik aktif selama tatap muka virtual; (3) orang tua membantu peserta didik dalam mengoperasikan aplikasi atau teknologi yang digunakan dalam belajar; (4) orang tua berkoordinasi dengan guru untuk penugasan.

Ada beberapa faktor yang mempengaruhi hasil belajar anak usia sekolah dasar yaitu faktor yang berasal dari diri peserta didik atau faktor internal dan faktor yang berasal di luar peserta didik atau faktor eksternal. Faktor internal meliputi kesiapan peserta didik, motivasi belajar, kebiasan belajar, fisik dan mental peserta didik. Sedankan faktor eksternal adalah orang tua, guru dan lingkungan. Untuk itu perlu adanya peran dari orang tua guna kesuksesan pembelajaran dengan model Distance learning. Orang tua menjadi kunci keberhasilan belajar di rumah sedangkan guru adalah kunci keberhasilan belajar di sekolah.

Keberhasilan dalam pembelajaran model Distance learning ditentukan dari kerjasama antara guru dan orang tua serta strategi guru maupun orang tua dalam pembelajaran. Menurut Gagne strategi pembelajaran meliputi sembilan aktifitas, yakni (1) menarik perhatian peserta didik; (2) memberikan informasi tujuan pembelajaran pada peserta didik; (3) mengulang pembelajaran yang bersifat prasyarat untuk memastikan peserta didik menguasainya; (4) memberikan stimulus; (5) memberikan petunjuk cara mempelajari materi yang bersangkutan; (6) menunjukan kinerja peserta didik terkait dengan apa yang sudah disampaikan; (7) memberikan umpan balik terkait dengan kinerja atau tingkat pemahaman peserta didik; (8) memberikan penilaian dan; (9) memberikan kesimpulan. ${ }^{8}$ Keberhasilan dari suatu model ataupun media pembelajaran tergantung dari karakteristik peserta didiknya. Sebagaimana yang diungkapkan oleh Nakayama bahwa dari semua literatur dalam e-learning mengindikasikan bahwa tidak semua peserta didik akan sukses dalam pembelajaran online. Ini dikarenakan faktor lingkungan belajar dan karakteristik peserta didik. ${ }^{9}$

73

${ }^{7}$ Farid Ahmadi, Guru SD di Era Digital (pendekatan, media, inovasi) (Semarang: CV. Pilar Nusantara, 2017). h.

${ }^{8}$ Mulyono, Strategi Pembelajaran: Menuju Efektifitas Pembelajaran di Abad Global (Malang: UIN-Maliki Press, 2012). h. 9-10

${ }^{9}$ Wahyu Aji, dkk. "Dampak Covid-19 Terhadap Implementasi Pembelajaran Daring Di Sekolah Dasar". Edukatif: Jurnal Ilmu Pendidikan, vol. 2 no, 1 (2020). h. 56 
Orang tua mempunyai peran yang cukup penting dalam pembelajaran model Distance learning. Pendampingan orang tua dalam Distance learning adalah upaya yang dilakukan orang tua dalam mendampingi anak belajar. Pendampingan orang tua dalam belajar anak merupakan upaya memberikan bantuan kepada anak dalam mengatasi problem yang dihadapi ketika pembelajaran jarak jauh. Adapun bentuk-bentuk pendampingan dalam belajar menurut Kartini Kartono (dalam Qomaruddin) diantaranya adalah (1) Menyediakan fasilitas belajar; (2) Memberikan motivasi atau mengawasi kegiatan belajar anak di rumah; (3) Mengawasi penggunaan waktu belajar di rumah; (4) Mengenal kesulitan-kesulitan anak dalam belajar; (5) Menolong anak dalam mengatasi kesulitan dalam belajar. ${ }^{10}$

Dari berbagai wawancara orang tua di kota Jayapura ada beberapa upaya yang dilakukan dalam mendampingi anaknya belajar di rumah secara jarak jauh (Distance learning), yakni (1) memberikan motivasi belajar; (2) menyediakan fasilitas guna mendukung belajar secara online; (3) meluangkan waktu untuk mendampingi anak dalam belajar. Anak usia sekolah dasar dalam belajarnya masih pada tahap pra operasional konkret. Anak belum mampu memahami secara langsung tanpa adanya benda-benda konktet. Disinilah peran orang tua untuk mengkonkretkan materi yang diterima secara online; (4) mengatur waktu belajar; (5) kerjasama dengan guru; (6) memberikan contoh keteladananya sebagai pengganti figure guru di sekolah.

Perkembangan kognitif anak usia 7-12 tahun ditandai kemampuan dalam proses berpikir untuk mengoperasikan kaidah-kaidah logika meskipun masih terikat dengan benda-benda konkret. Selain itu, anak telah mengetahui simbol-simbol matematis, namun belum dapat memahami hal-hal yang abstrak. Dengan perkembangan kognitif anak seperti ini maka dalam pembelajaran model Distance learning membutuhkan pendampingan yang khusus. Karena anak belum tentu memahami materi tang dilihat di TV, Youtube, google classroom atau WA grup. Anak membutuhkan penterjemah dari materi yang disampaikan guru melalui media tersebut. Orang tua harus melungkan waktu untuk mendampingi anak daam belajar melalui daring. Pendampingan ini tidak sekedar mendampingi di sampingnya tetapi harus bisa mengidentifikaasi kesulitan-kesulitan dalam belajar anak serta memberikan solusi dan moticvasi dalam menyelesaikan kesulitan tersebut.

Untuk keberhasilan dalam proses pembelajaran model Distance learning orang tua harus bersinergi dengan guru (kerjasama). Kerja sama dapat dilakukan melalui grup wa, menyamakan persepsi dalam pembelajaran Distance learning, mengatur waktu atau jadwal pembelajaran. Selain itu, guru dan orang tua dapat menyampaikan peningkatkan hasil belajar selama pembelajaran model Distance learning. Untuk mengawasi kegiatan anak di rumah guru bisa membuat kartu pengendali dengan menggunakan google form yang setiap hari harus di sis orang tua mengenai kegiatan belajar dirumah.

${ }^{10}$ Qomaruddin, "Pendampingan Orang tua terhadap pendidikan anak”. Jurnal Studi Keislaman. Vol. 3 (2017). h. 
Dari pemaparan diatas maka dapat disimpulkan peran orang tua dalam pendampingan pembelajaran model Distance learning sebagai berikut:

1. Educator

Educator atau sering disebut pendidik, yang mengandung arti orang yang memberikan pengaruh pembinaan kepada peserta didik baik melalui lembaga formal maupun non formal agar dapat mengembangkan potensinya. Pendidik dalam pendidikan Islam diartikan orang yang bertanggung jawab terhadap perkembangan peserta didik baik dari segi kognitif, afektif dan piskomotorik. Pendidik terbagi menjadi dua yaitu pendidik kodrat dan pendidik jabatan. Pendidik kodrat adalah orang yang mempunyai hubungan darah dengan peserta didik atau sering di sebut dengan orang tua. Sedangkan pendidik jabatan adalah orang mendidik dan mengajar peserta didik dalam lembaga pendidikan baik formal maupun nin formal seperti guru.

Orang tua sebagai pendidik dalam Distance learning dapat dipahami sebagai pembimbing maupun pengajar bagi anak-anaknya di era covid-19. Sebagai seorang pembimbing/ pengajar atau guru dalam belajar di rumah orang tua harus memahami karakteristik anaknya, gaya belajar anak dan strategi belajar yang memudahkan anak memahami materi yang di ajarkan atau memberikan penjelasan materi yang berikan guru melalui pembelajaran daring. Selain itu orang tua sebagai educator tidak hanya terpaku dalam mengembangkan kognitif anak, tetapi ketiga aspek kognitif, sosial dan keterampilan harus dikembangkan secara berbarengan. Hal ini sesuai dengan amanah negara yang tertuang dalam Undang-Undang Sisdiknas, yakni tujuan dari pendidikan adalah mewujudkan suasana belajar dan proses pembelajaran agar peserta didik secara aktif mengembangkan potensi dirinya untuk memiliki kekuatan spriritual keagamaan, pengendalian diri, kepribadian, kecerdasan, akhlak mulia serta keterampilan yang diperlukan dirinya, masyarakat, bangsa dan negara.

\section{Motivator}

Motivasi berasal dari kata motif yang artinya dorongan atau alasan. Motivasi dalam pembelajaran dapat dimaknai suatu dorongan peserta didik untuk mencapai tujuan belajar yang telah ditetapkan. Pendampingan orang tua dalam belajar secara online sangat penting bagi anak terutama dalam memberikan motivasi belajar. Anak usia sekolah dasar dengan karakteristik senang bermain membutuhkan cara yang khusus dalam hal belajar. Dalam hal ini orang tua bisa memberikan motivasi secara terus-menerus dalam distance learning. Tanpa motivasi dari orang tua biasaya anak akan malas dalam belajar. Motivasi dan belajar dua hal yang tidak bisa dipisahkan karena keduanya saling mempengaruhi. Beberapa faktor yang mempengaruhi motivasi belajar, yaitu hasrat dan keinginan berhasil, harapan dengan cita-cita. Selain itu motivasi dapat timbul dengan adanya penghargaan, lingkungan belajar yang kondusif dan kegiatan yang menarik. Untuk itu orang tua harus mampu memberikan motivasi belajar pada anak di era covid 19, dengan lamanya belajar dirumah dan jarang bertemu teman sekolahnya membuat gairah belajar anak menurun. 
Syaiful Bahri Djamarah menjelaskan agar peranan motivasi belajar dapat berperan secara maksimal maka perlu memperhatikan beberapa prinsip, yakni (1) menjadikan motivasi sebagai penggerak dasar dalam aktifitas belajar; (2) lebih mengutamakan motivasi intrinsik dari pada motivasi ekstrinsik; (3) lebih mengutamakan motivasi dalam bentuk pujian daripada hukuman; (4) motivasi harus berhubungan dengan kebutuhan belajar; (5) motivasi harus memumuk rasa optimisme dalam belaja; (6) motivasi harus melahirkan prestasi belajar (Djamarah, 2011, hal. 152-155). Orang tua sebagai motivator dalam belajar anak di rumah harus memahami prinsip-prisip dalam memberikan motivasi belajar. Motivasi belajar mempunyai pengaruh yang besar bagi anak dalam belajar di rumah. Dengan motivasi yang diberikan oleh orang tua maka anak dapat menikmati dalam proses pembelajaran dengan model distance learning.

3. Fasilitator

Salah satu peran orang tua dalam pembelajaran model distance learning bagi anak usia sekolah dasar adalah fasilitator. Dalam hal ini orang tua harus memberikan fasilitas atau kemudahan bagi anaknya dalam belajar jarak jauh, seperti menyediakan keperluan atau perlengkapan yang mendukung distance learning seperti menyiapkan tempat belajar yang nyaman, peralatan belajar yang memadahi (HP/ Kumputer, jaringan internet, buku dan peralatan tulis). Orang tua harus mampu menghadirkan berbagai sumber belajar yang menunjang distance learning. Sumber belajar dapat berupa buku teks, majalah, koran, youtube atau video dari gurunya.

4. Inspirator

Orang tua di rumah mejadi model bagi anaknya seperti guru menjadi model dalam sekolah. Guru dalam bahasa Jawa di artikan digugu dan di ditiru. Orang tua harus mempunyai peran seperti ini, yakni digugu atau ditaati dan di tiru atau di contoh. Orang tua sebagai teladan bagi anaknya dimasa covid-19. Banyak orang tua yang terlena denga peran ini. Dalam era covid-19 orang tua cenderung memberikan fasilitas dalam belajar anak tetapi lupa ada salah satu peran guru yang harus diperankan. Dalam hal perilaku/ akhlak anak tidak hanya sebatas membaca atau mendengarkan materi dari gurunya tanpa melihat langsung secara kongkret perilaku tersebut. Pembentukan akhlak melalui beberapa tahapan yakni pembentukannya yakni Receiving (menerima), Responding (menanggapi), acting (bertindak) dan being (melakukan seperti yang diketahui) dalam kehidupannya baik dilingkungan keluarga, sekolah maupun masyarakat. ${ }^{11}$ Dalam hal ini orang tua harus bekerja sama dengan guru. Berdasarkan data yang diperoleh, ada beberapa temuan yang dilakukan orang tua dalam bekerjasama dengan gurunya, diantaranya adalah (1) membuat WAG (whatsaap Grup) yang digunakan untuk alat komuniasi dan melaporkan perkembangan anak baik secara audio, visual ataupun secara audio-visual; (2) mengisi buku penghubung, buku ini berisi aktivitas anak selama belajar di rumah; (3) membuat penilaian orang tua yang di isi oleh peserta didik. Hal ini dilakukan agar program

${ }^{11}$ Didik Efendi, "Proses Pembentukan Aqidah dan Akhlak Pada Siswa Sekolah Dasar di Kota Jayapura". AlAdzka: Jurnal Ilmiah Pendidikan Guru Madrasah Ibtidaiyah. Vol. 9 No. 1 (2019). h. 27 
belajar dirumah dapat belajar sesuai dengan harapan serta orang tua bisa mengambil peran guru secara maksimal di rumah.

Orang tua juga bisa menjadi pencetus ide-ide kreatif dan inovatif dalam distance learning yang dapat dilakukan oleh anaknya, seperti semboyan “ing ngarso sung tulodho”. Orang tua menjadi model utama dalam distance learning, melalui orang tua anak bisa belajar bagaimana cara berbahasa, perbuatan dan keseharian orang tua dirumah.

\section{Problem Orang Tua Dalam Pendampingan Pembelajaran Model Distance Learning}

Problem yang dihadapi para orang tua dalam pembelajaran model distance learning adalah penambahan pengeluaran untuk membeli paket data internet, menyita waktu bekerja orang tua untuk mendampingi anaknya belajar di rumah, Orang tua harus memberikan fasilitas dalam pembelajaran jarak jauh dan membimbing anaknya dalam mengoperasikan fasilitas tersebut. ${ }^{12}$ Dari hasil wawancara problem yang di hadapi orangh dalam pendampingan pembelajaran model distance learning adalah (1) kesulitan mengatur waktu, dimana satu rumah ada tiga lebih anak yang belajar daring; (2) jaringan yang kurang stabil membuat pembelajaran kurang maksimal; (3) banyaknya orang tua yang gaptek (gagap teknologi) membuat kesulitan dalam pendampingan; (4) membutuhkan kesabaran yang cukup tinggi; (5) cara pendampingan ketika orang tuanya masuk kerja. Disamping itu, banyak ekonomi orang tua yang menengah kebawah sehingga tidak mampu menyediakan fasilitas anaknya untuk mengikuti pembelajaran daring.

\section{SIMPULAN}

Berdasarkan hasil penelitian peran orang tua dalam pembelajaran model distance learning di kota Jayapura dapat dikesimpulan bahwa peran orang tua dalam pembelajaran model distance learning ada empat peran yakni, educator, motivator, fasilitator dan inspirator. Adapun problem yang dihadapi orang tua dalam pembelajaran model distance learning adalah kesuliatan mengatur waktu, jaringan yang kurang stabil, orang tua yang gaptek (gagap teknologi), membutuhkan kesabaran yang cukup tinggi dan cara pendampingan ketika orang tuanya masuk kerja.

\section{DAFTAR PUSTAKA}

Ahmad Susanto, Teori Belajar dan Pembelajaran di Sekolah Dasar. Jakarta: Kencana, 2013

Agus Purwanto, dkk, "Studi Eksploratif Dampak Pandemi Covid-19 Terhadap Proses Pembelajaran Online di Sekolah Dasar", Journal of Education, Psychology and Counseling Vol, 2 No. 1 (2017)

Didik Efendi, "Proses Pembentukan Aqidah dan Akhlak Pada Siswa Sekolah Dasar di Kota Jayapura". Al-Adzka: Jurnal Ilmiah Pendidikan Guru Madrasah Ibtidaiyah. Vol. 9 No. 1 (2019).

Dimyati, Mudjiono, Belajar dan Pembelajaran. Jakarta: PT Rineka Cipta, 2006

${ }^{12}$ Agus Purwanto, dkk, "Studi Eksploratif Dampak Pandemi Covid-19 Terhadap Proses Pembelajaran Online di Sekolah Dasar", Journal of Education, Psychology and Counseling Vol, 2 No. 1 (2017). 
Didik Efendi : Peran Orang Tua Dalam Pembelajaran Model Distance Learning di Sekolah Dasar Kota Jayapura

Farid Ahmadi, Guru SD di Era Digital (pendekatan, media, inovasi. Semarang: CV. Pilar Nusantara, 2017

Fauzan, Kurikulum \& Pembelajaran. Tangerang Selatan: Gaung Persada (GP) Press, 2017

Mulyono, Strategi Pembelajaran: Menuju Efektifitas Pembelajaran di Abad Global. Malang: UIN-Maliki Press, 2012

Nana Syaodih Sukmadinata, Metode Penelitian Pendidikan. Bandung: PT Remaja Rosdakarya, 2015

Oemar Hamalik, Psikologi Belajar dan Mengajar. Bandung: Sinar baru Algensindo, 2007

Qomaruddin, "Pendampingan Orang tua terhadap pendidikan anak”. Jurnal Studi Keislaman. Vol. 3 (2017)

Wahyu Aji, dkk. "Dampak Covid-19 Terhadap Implementasi Pembelajaran Daring Di Sekolah Dasar”. Edukatif: Jurnal Ilmu Pendidikan, vol. 2 no, 1 (2020)

Al-Madrasah: Jurnal Ilmiah Pendidikan Madrasah Ibtidaiyah Vol. 5, No. 1, Juli-Desember 2020 